\title{
Digitizing and Schematizing the Archival Material from the Late Ottoman Period Found in the Monastery of al-Za'farān in Southeast Turkey
}

By Iskandar Bcheiry, ATLA

\begin{abstract}
In the context of combining digital humanities with scholarship in history and religion, my paper discusses a plan to create a relational database of primary sources that were found in Syriac Orthodox monastery in southeast Turkey. The primary sources are in the form of archives of correspondence to and from six Syriac Orthodox patriarchs during the nineteenth and early twentieth centuries. This massive archive comprises around 20,000 documents, which are still unpublished, and their content is mostly unknown to the scholarly world. In this proposed database of the Syriac patriarchal archives, the data extracted from the sources will be stored according to a relational aspect. The big picture of this project is to create a tool not only to understand many aspects of the life of the Syriac community in the Middle East and in direct relationship with other communities who lived beside them or interacted with them, but also to develop a tool for other scholars in different fields and geographical areas to interact with this relational database according to their own interests.
\end{abstract}

\section{INTRODUCTION}

In April 2002, I had the opportunity to examine a collection of Arabic and Syriac manuscripts in the Library of the Syriac Orthodox Church of the Forty Martyrs in Mardin, the Library of the Syriac Orthodox Church of St. Mary in Diyarbakir, and the Library of the monastery 


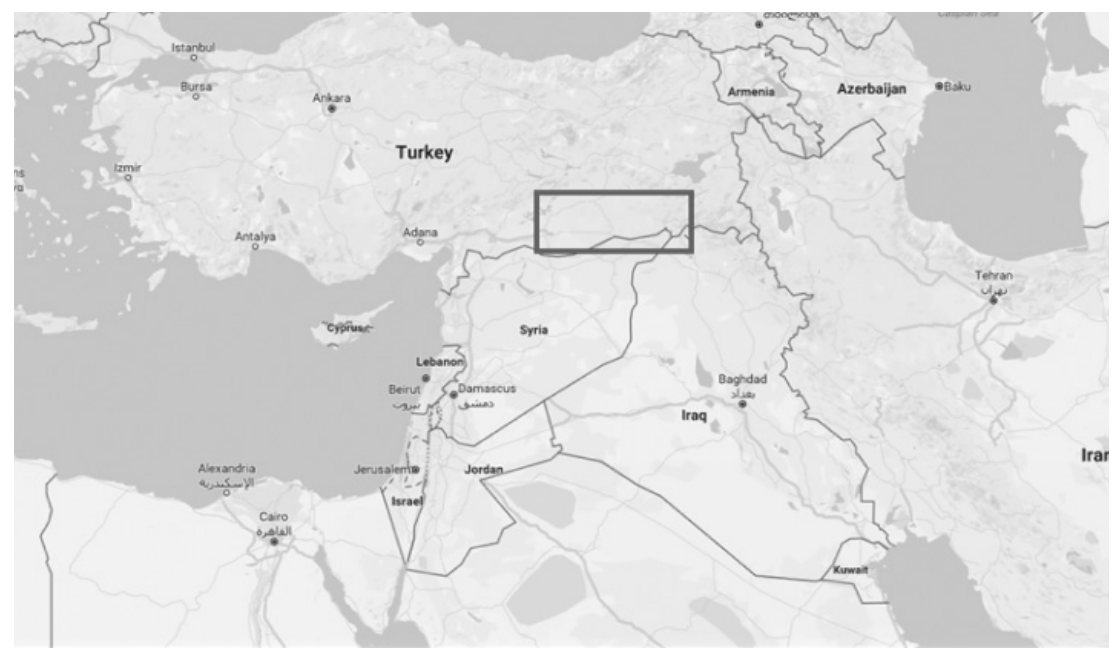

FIGURE 1 Southeast Turkey and the surrounding regions

of al-Za'farān in southeast Turkey. This was all due to permission from the late Patriarch Ignatius Zakkā I Iwās (d. 2014) and a grant provided for my research by the Italian Institute for Philosophical Studies, Naples, Italy. Besides the subject of my intended study and examination, I had a glimpse of the archives that were stored in the library of the Church of Forty Martyrs in Mardin in the form of reports, letters, and communications which were originally brought from Dayr al-Za'farān, which is located eight kilometers east of the city of Mardin. A few years later, in 2010, a team of researchers led by Archbishop Yuhannā Ibrahīm of Aleppo examined and photographed nearly 20,000 documents in Mardin and Dayr al-Za'farān. At this year's ATLA Annual Conference in Indianapolis, Indiana, I illuminated the importance of this historical collection. I also presented a basic plan of a database for the historical records extracted from the materials of this collection of documents.

\section{BRIEF HISTORY}

The Syriac Christians are the indigenous inhabitants of Syria and Mesopotamia who embraced Christianity in the first centuries of its history. During the fifth century, because of the Christological controversies as the result of the councils of Ephesus in 431 and Chalcedon in 451, the Syriac Christians became divided among Nestorians, Chal- 
cedonians, and non-Chalcedonians. By the early sixth century, most Syriacs of east Syria and Upper Mesopotamia supported the nonChalcedonian Christology, whose greatest theologian at the time was Severus of Antioch (c. 465-538). During the rule of Emperor Justin I (519-521), as well under the rule of Emperor Justinian (527-565), the Syriac non-Chalcedonian Christians experienced persecution. In the second half of the sixth century, Jacob Baradeo organized the Non-Chalcedonian Syriac Orthodox church by ordaining thousands of deacons, priests, and bishops; in this way he consolidated the NonChalcedonian faith and revived the Syriac Orthodox church.

The Arab Muslim conquest of the Byzantine and Persian territory in the Near East in the seventh century stopped the Byzantine persecutions. However, the Christian Syriacs, as well as other Christian groups and Jews, found themselves as a protected non-Muslim community under Muslim rule. The Syriac Christians experienced difficult times during the conflict between the Crusaders, Mamelukes, and Mongols during the twelve and thirteenth centuries. The Mongol invasion led by Tamerlane (d. 1405) in the late fourteenth century caused great destruction and losses. By the sixteenth century, the Syriac Christians were ruled by the Ottomans, who dominated the entire Near East. By the eighteenth and nineteenth centuries the Christian Syriacs were greatly weakened, and their main presence was limited to few regions in Syria and Mesopotamia such as in southeastern Anatolia, western Syria, and northern Iraq. During the twentieth century, a radical demographic shift occurred as the result of systematic massacres by the

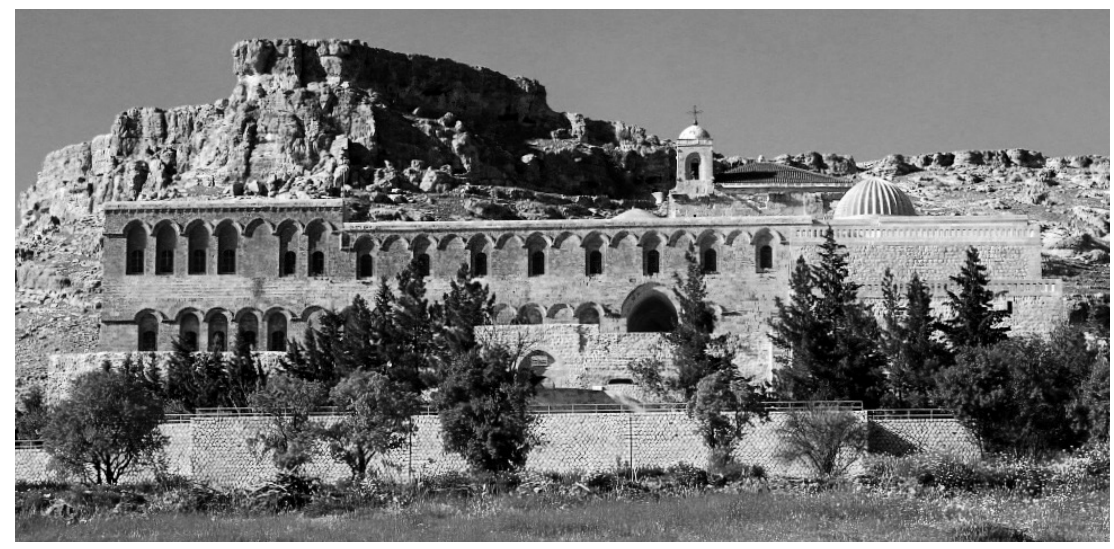

FIGURE 2 The monastery of Dayr al-Za'farān in Southeast Turkey 
Ottoman government during the First War World (1915-1918). Around 100,000 Syriac Orthodox perished during this massacre. During the early years of the Republic of Turkey, the Syriac Orthodox Patriarchate was transferred to Homs, Syria, in 1933, and then in 1959 to Damascus, where it remains today. Nowadays, the Syriac Christians are found in Syria, Lebanon, Iraq, and Turkey, with a noticeable presence in Germany and Sweden.

\section{THE MONASTERY OF DAYR AL-ZA'FARĀN}

The monastery of Dayr al-Za'farān is located eight kilometers east of the city of Mardin in southeast Turkey, situated on the hills overlooking the northeastern Syrian plains. Dayr al-Za'farān was originally built on the pre-Christian foundations of a pagan temple dedicated to the worship of the sun, which may date to around 1000 в.с. The temple complex was later used by the Romans as a fort, and after they abandoned it, a certain monk named Morī Šlaymūn converted the buildings into a monastery. Though it was originally named after Morī Šlaymūn, the monastery was later named for Morī Šananyā (Ananias), the metropolitan bishop of Mardin and the surrounding region (793-800) who rebuilt and renovated the monastery. Since the fifteenth century it has been called the "Saffron Monastery" due to the saffron-colored stone of the buildings. From 1160 until 1932, the monastery became the seat of the Syriac Orthodox Patriarch. Today the monastery is the seat of the bishopric of Mardin, and besides being a religious building, the monastery is also an important tourist landmark visited by thousands of people each year.

\section{SYRIAC ORTHODOX PATRIARCHAL ARCHIVES}

The library of the monastery of al-Za'faran and the Church of the Forty Martyrs in Mardin are not only depositories of a large collection of Syriac and Arabic manuscripts, but they also are places for more than 20,000 documents of archives that were collected mostly during the nineteenth century and the early years of the twentieth century. Much of this archive is in the form of correspondence to and from the patriarchate over a period that extends more than a century beginning from the early 1820s. Being the seat of the Patriarchs of the Syrian Orthodox Church for over nearly seven centuries, Dayr al-Za 'faran was the major depository of church documents for a long time. Between 2005 and 
2010 a team led by Archbishop Yuhanna Ibrahim and Dr. Khalid Denno examined much of this collection of archives, taking nearly 20,000 images. A preliminary description of the archives and their importance was made by Dr. Denno in his book Syrian Orthodox Christians in the Late Ottoman Period and Beyond: Crisis Then Revival (Gorgias Eastern Christian Studies), published by Gorgias Press in 2017.

\section{THE CONTENTS AND SIGNIFICANCE OF THE ARCHIVES}

The contents of the letters, reports, and communications found in the archives describe the daily life of the Syriac Christian community chiefly during the nineteenth century. The archives also report about the Syriac Christians' relationship with the Ottoman government in Constantinople and the districts in southeastern Anatolia, the relationship with the neighboring Muslim community, and the relationship with other Christian communities such as Armenians, Chaldeans, Nestorians, Catholics, and Protestants. The letters were addressed to the patriarch of the day from different people such as bishops, abbots, heads of monasteries, priests, monks, deacons, secular leaders in the Syriac communities, and keepers responsible for collecting donations and patriarchal dues, as well as from Muslim people, functionaries of the government, and foreign counselors. The archives are important from social, religious, historical, political, topographical, cultural, religious, and juridical aspects and provide valuable insight into the contemporary life of the Syriacs in many dimensions.

\section{EXAMPLES OF ISSUES AND TOPICS FOUND IN THE ARCHIVES}

Reports about local conflicts in villages

Petitions against the agents and keepers of the patriarchs

Petitions from prisoners

Petitions because of injustice and assaults

Petitions against clergy: priests and monks because of financial issues

Appeals against Armenians' assaults and pressure

Reports about collecting the dues and the incomes of monasteries and churches 
Petitions regarding cases in courts

Reports about family disputes

Reports about ecclesiastic appointments

Reports about issues and news from India

Correspondences from the Russian counselor in Aleppo

Reports about disputes with Syriacs converted to Catholicism

Reports about churches and monasteries' endowments Reports about the patriarch's visits and journeys Reports about rebuilding and renewing churches Protesting bishops because of their bad management Petitions for marital issues and juridical decisions Reports about local church administrations Conflicts within the same congregation in different places Petitions regarding social and ethical conducts Petitions against bandit's assaults Petitions about the administration of monasteries Petitions from Muslim people asking for help from the patriarch

Petitions about selling and renting lands, houses, and pits Petitions from women against their husbands

Petitions for peacemaking between Muslims and Christians in local villages

Reports about Catholic missionary activities among the local people

Reports about Protestant missionary activities among the local people

Reports about assaults against monks by the local governors Reports about assaults against shepherds and the seizing of their livestock

Petitions regarding the collection of the agriculture products in some villages

Petitions against the local Muslim governors and their prejudices against Christians 
Petitions in seeking financial support for priests of certain local parishes

Reports about kidnapping women and forced marriages

Petitions about cases of marriage between Syriac people with other Christian groups such as Armenians, Catholics, and Protestants

Reports about the expenses of restoring churches and monasteries

Petitions to the patriarch asking his interference toward the government

Petitions and reports about juridical matters and legal cases in courts

Petitions describing the legal authority of the patriarch in the civil law courts

Creating a database of the archives

The goal of my project is to create a database in which the data extracted from the sources will be stored. After capturing the data from the sources and putting it into the created database, it would be important to look for a relationship between the data stored in the database. The big picture of this project is to create a tool not only to understand many aspects of the life of the Syriac community in southeastern Anatolia and in direct relationship with other communities who lived beside them or interacted with them, but also for other scholars in different fields and geographical areas to interact with this relational database according to their own interests.

\section{KEY ASPECTS}

The data of the Archives' contents would be structured and presented according to several key aspects: period; sender; geographic provenance; subject matter; and language of correspondence:

\section{PERIOD}

The letters are defined chronologically according to the reign of patriarchs, because the date is often not stated, while the name of the patriarch is almost always mentioned. The timeframe for the reigns of patriarchs under question follows. 
An example of geographical locations found in the archives

\begin{tabular}{|c|c|c|}
\hline LOCATION & PRESENT NAME & $\begin{array}{c}\text { DISTRICT/PROVINCE } \\
\text { (most of the locations are in Turkey) }\end{array}$ \\
\hline ‘Alūzì & Alluz & Bismil/Diyarbakir \\
\hline 'Amīrīn & Kocapinar & Cizre/Sirnak \\
\hline 'Amsū & Guvercin & Center/Batman \\
\hline 'Arbāyyah & Alayurt & Dargecit/Mardin \\
\hline 'Arnes & Bağlarbaşı & Midyat/Mardin \\
\hline 'Arnez & Beşpınar & Besiri/Batman \\
\hline ‘Ayn Sarī & Pinarbasi & Idil/Sirnak \\
\hline 'Ayn Ward & Gülgöze & Midyat/Mardin \\
\hline ‘Ayndār & Ağaçlıpınar & Kurtalan/Siirt \\
\hline 'Azkī & Değirmenüstü & Besiri/Batman \\
\hline Al-Herbah & Harapjar & Kurtalan/Siirt \\
\hline Al-Hsayniyyah & Huseynan & Silvan/Diyarbakir \\
\hline $\mathrm{Al}-\mathrm{Hūb}$ & Asmadere & Besiri/Batman \\
\hline Al-Husayniyyah & Aydemir & Kurtalan/Siirt \\
\hline Al-lbrāhīmiyyah & Isiklar & Center/Mardin \\
\hline Al-Krīdiyyah & Köşetarla & Center/Batman \\
\hline Al-Malāḥah & Yunluce & Lice/Diyarbakir \\
\hline Al-Mareğ & Suluyazi & Sirvan/Siirt \\
\hline Anḥel & Yemişli & Midyat/Mardin \\
\hline Arbū & Taskoy & Nusaybin/Mardin \\
\hline Aznāwūr & Sinirtepe & Nusaybin/Mardin \\
\hline Badlīs & Bitlis & Center/Bitlis \\
\hline Bāfāwā & Kayadere & Ömerli/Mardin \\
\hline
\end{tabular}

1. Elias II (1838-1847)

2. Jacob II (1847-1871)

3. Peter III/IV (1872-1894)

4. Abdul Masih II (1895-1903)

5. Abdullah II (1906-1915)

6. Elias III (1917-1932) 


\section{SOURCE (SENDER) IDENTITY}

Letters to the patriarch of the day came from different people, such as bishops, priests, monks, and deacons; church keepers and community notables; ordinary folk, individuals, and groups of individuals; other Christians and Christian churches; Muslim neighbors; public and regional authorities; foreign diplomatic sources; and the Sublime Porte.

\section{GEOGRAPHIC PROVENANCE}

Most of the letters came from southeastern Anatolia, while a smaller number of letters came from Iraq, Syria, and Istanbul.

\section{LANGUAGE}

Most of the documents were chiefly written in Arabic Garshuni, which means in Arabic language but in Syriac script. However, there are documents written in Ottoman Turkish, Arabic, or Syriac; a few documents from India and Europe in English; and some letters in Armenian.

Geographic Provenance

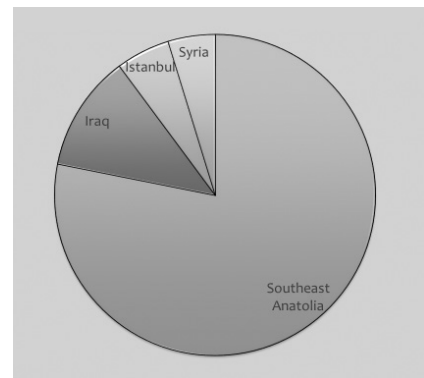

FIGURE provenance percentage
Language

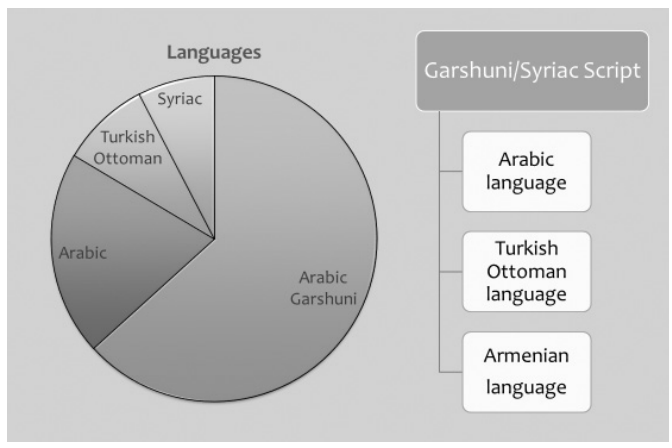

FIGURE 4 Languages 


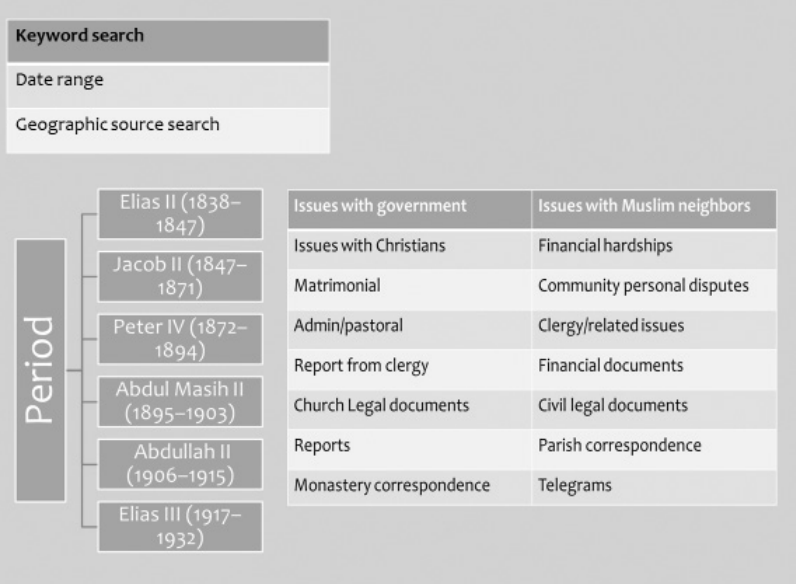

FIGURE 5 An example of basic database contents

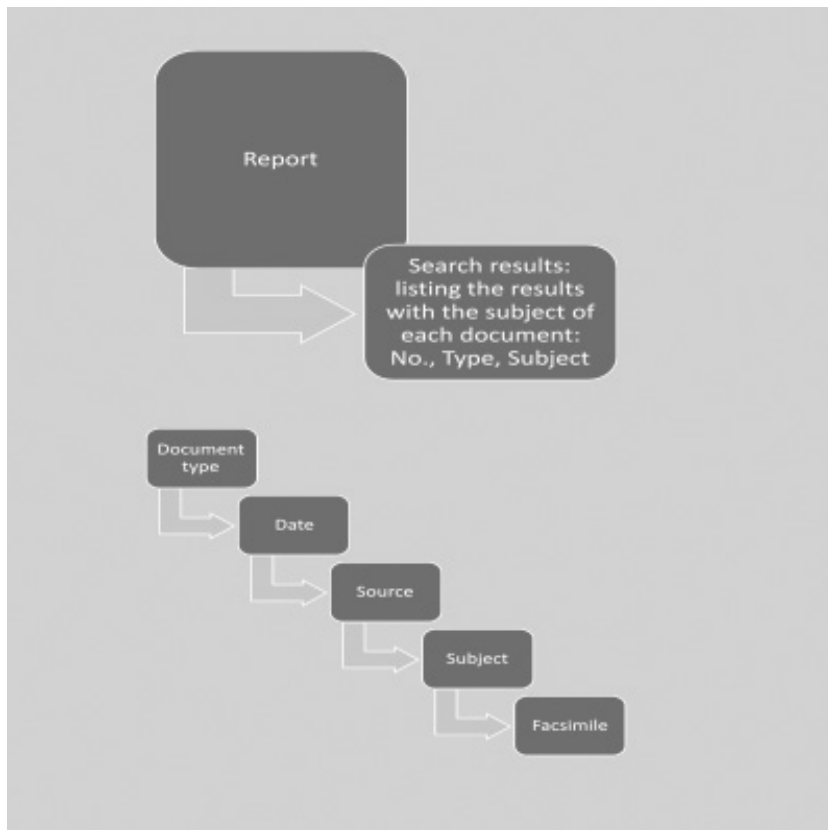

FIGURE 6 An example of basic database contents 


\section{CONCLUDING REMARKS}

The archives that are preserved in the monastery of Dayr al-Za'farān and the Church of the Forty Martyrs in Mardin bear a special interest not only for the history of the Syriac Christian community but also for Ottoman history. The archives of letters and correspondence contain an immense amount of material from ordinary people, and thus they present the state of a society viewed from below. Creating a database for this archive will benefit a diverse group of people. It will provide access to a primary source of information about the historical, cultural, and religious diversity of the Middle East. It will offer an unlimited mine of historical information to scholars and academics, which will generate new scholarly interest in Syriac and Ottoman studies. Finally, the database will bring new ways of understanding history through digital approaches.

\section{BIBLIOGRAPHY}

Barsoum, Ignatius Aphram, History of the Zaffaran Monastery. Translated by Moosa, Matti. Piscataway, New Jersey: Gorgias Press, 2008.

Bcheiry, Iskandar. "Relational Database of Syriac and Arabic Historical Registers,” ATLA Proceedings 71 (2017): 32-38.

Bcheiry, Iskandar. "The Syriac Community in Batman and its Vicinity According to the Archives of the Ecclesiastical Consecrations Conserved in the Church of Forty Martyrs in Mardin, South East of Turkey," Adnan Cevik ed., I. Uluslararası Batman ve Çevresi Tarih ve Kültür Sempozyumu Bildiriler, c.1. Istanbul (2009): 410-418.

Dinno, Khalid. Syrian Orthodox Christians in the Late Ottoman Period and Beyond: Crisis Then Revival (Gorgias Eastern Christian Studies). Piscataway, N.J: Gorgias Press, 2017. 
APPENDIX A sample of historical documents: Three examples of letters to patriarch Ignatius 'Abd al-Masīh al-Qal'atmarāwī (18951903) with the signatures of clergy and secular leaders of some villages in southeast Anatolia.
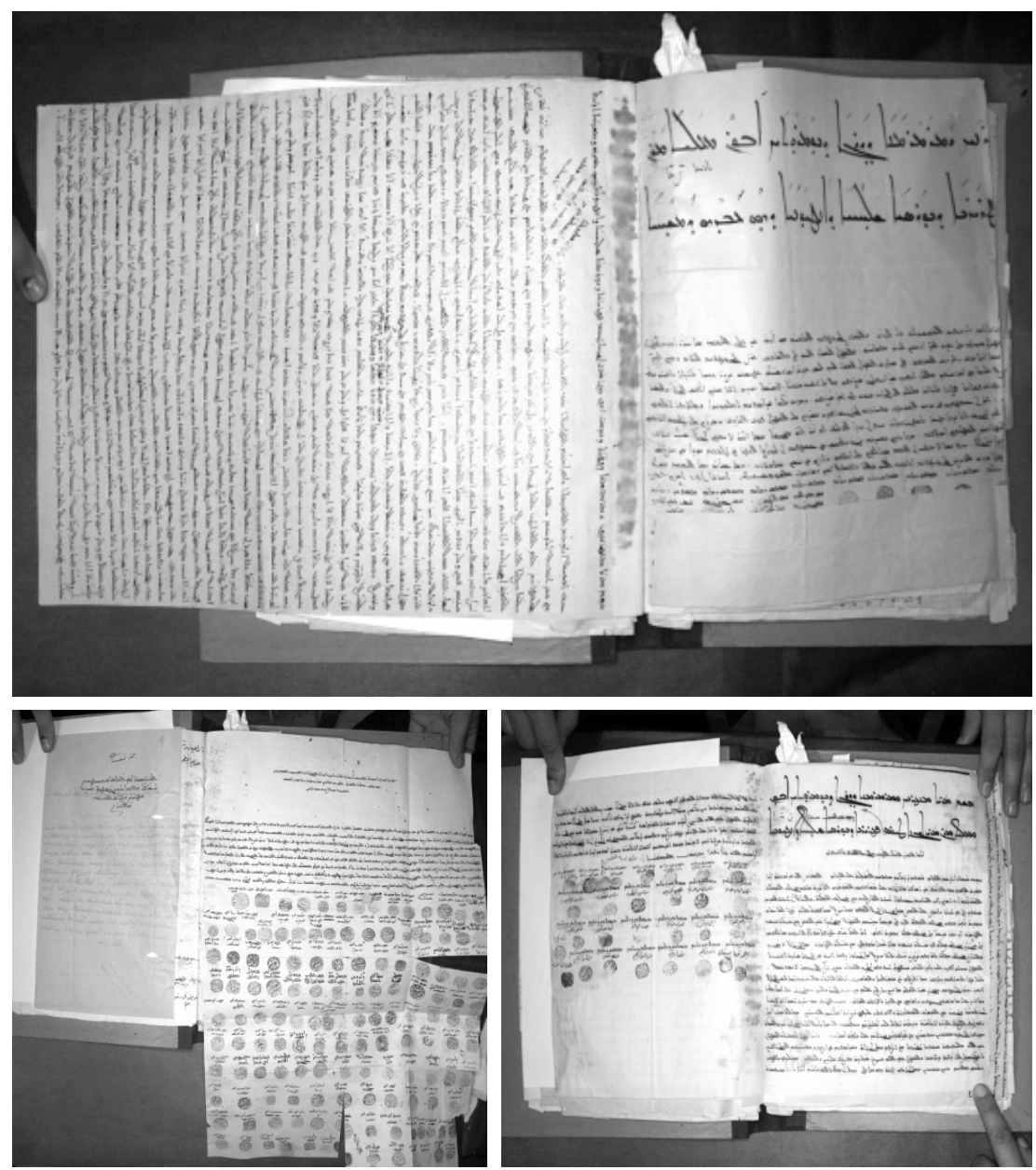